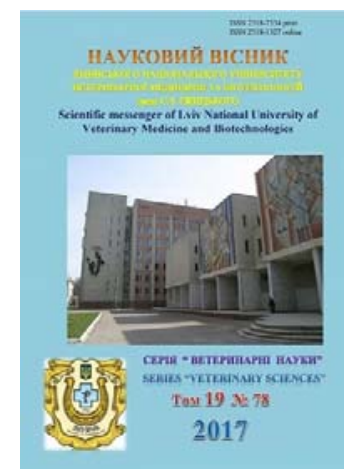

Науковий вісник Львівського національного університету ветеринарної медицини та біотехнологій імені С.З. Гжицького

Scientific Messenger of Lviv National University of Veterinary Medicine and Biotechnologies

doi:10.15421/nvlvet7810

ISSN 2518-7554 print

ISSN 2518-1327 online

$\underline{\text { http://nvlvet.com.ua/ }}$

УДК 619:614.31:639.331.5

\title{
Ідентифікація небезпечних чинників під час вирощування райдужної форелі в умовах замкнутого водопостачання
}

\author{
Н.С. Гриневич ${ }^{1}$, Т.М. Димань ${ }^{1}$, М.Д. Кухтин ${ }^{2}$, В.І. Семанюк ${ }^{3}$, А.О. Слюсаренко ${ }^{1}$ \\ gnatbc@ukr.net \\ ${ }^{1}$ Білочерківський національний аграрний університет, \\ пл. Соборна, 8/1, Біла Церква, 09111, Украӥна; \\ ${ }^{2}$ Тернопільський національний технічний університет імені І. Пулюя, \\ вул. Руська, 56, м. Тернопіль, 46001, Україна; \\ $3^{3}$ Лвівський наиіональний університет ветеринарної медицинии біотехнологій імені С.З. Гжицького, \\ вул. Пекарська, 50, м. Львів, 79010, Украӥна
}

\begin{abstract}
Проведено ідентифікаціюо небезпечних чинників для умовного індустріального господарства з вирощування райдужної форелі в умовах замкнутого водопостачання. Під час аналізу небезпечних чинників визначали ступінь суттєвого впливу $i$ вірогідності потенційних небезпек. Суттєві потенційні небезпеки визначили на таких технологічних етапах, як осіменіння та інкубація ікри, витримування личинки, реалізачія ікри, личинки, молоді, товарної риби і плідників. Крім суто технологічних, мають місие додаткові небезпечні чинники - пов'язані з функиіонуванням біофільтра, годівлею риби $і$ застосуванням лікувально-профілактичних та дезінфекційних засобів. Ідентифіковані в роботі потенційні небезпеки важливо враховувати під час складання плану НАССР у форелевих господарствах.

Ключові слова: небезпечний чинник, НАССР, контрольні критичні точки, аквакультура, райдужна форель, установки замкнутого водопостачання.
\end{abstract}

\section{Идентификация опасных факторов при выращивании радужной форели в условиях замкнутого водоснабжения}

\author{
Н.С. Гриневич ${ }^{1}$, Т.М. Димань ${ }^{1}$, М.Д. Кухтин ${ }^{2}$, В.І. Семанюк ${ }^{3}$, А.О. Слюсаренко ${ }^{1}$ \\ gnatbc@ukr.net \\ ${ }^{I}$ Белочерковский национальный аграрный университет, \\ пл. Соборная, 8/1, Белая Церковь, 09111, Украина; \\ ${ }^{2}$ Тернопольский наџиональный технический университет им. И. Пулюя, \\ ул. Русская, 56, г. Тернополь, 46001, Украина; \\ $3^{3}$ Лвовский национальный университет ветеринарной медициныи биотехнологий имени С.З. Гжиџкого, \\ ул. Пекарская, 50, м. Львов, 79010, Украина
}

\begin{abstract}
Проведена идентификаиия опасных факторов для условного индустриального хозяйства по вырашиванию радужной форели в условиях замкнутого водоснабжения. При анализе опасных факторов определяли степень существенного влияния и вероятности потенциальных опасностей. Существенные потенциальные опасности определили на таких технологических этапах, как осеменение и инкубация икры, выдерживание личинки, реализация икры, личинки, молоди, товарной рыбы и производителей. Кроме чисто технологических, имеют место дополнительные опасные факторы - связанные с функиионированием биофильтра, кормлением рыбы и применением лечебно-профилактических и дезинфекиионных средств. Иден-
\end{abstract}

Citation:

Grynevych, N., Dyman, T., Kukhtyn, M., Semanyuk, V., Sliusarenko, A. (2017). Identification of dangerous factors on rainbow trout farms with Recurculating aquaculture system. Scientific Messenger LNUVMB, 19(78), 48-52. 
тифицированные в работе потенциальные опасности важно учитывать при составлении плана НАССР в форелевих хозяйствах.

Ключевые слова: опасный фактор, НАССР, контрольные критические точки, аквакультура, радужная форель, установки замкнутого водоснабжения.

\title{
Identification of dangerous factors on rainbow trout farms with Recurculating aquaculture system
}

\author{
N. Grynevych ${ }^{1}$, T. Dyman ${ }^{1}$, M. Kukhtyn ${ }^{2}$, V. Semanyuk ${ }^{3}$, A. Sliusarenko ${ }^{1}$ \\ gnatbc@ukr.net \\ ${ }^{I}$ Bila Tserkva National Agrarian University, \\ Soborna sq., 8/1, Bila Tsercva, 09111, Ukraine; \\ ${ }^{2}$ Ternopil Ivan Pul'uj National Technical University, \\ Ruska Str. 56, Ternopil, 46001, Ukraine; \\ ${ }^{3}$ Stepan Gzhytskyi National University of Veterinary Medicine and Biotechnologies Lviv, \\ Pekarska Str., 50, Lviv, 79010, Ukraine
}

\begin{abstract}
Identification of dangerous factors for a conditional industrial farm for rainbow trout growing in conditions of Recurculating aquaculture system (RAS) was carried out. During the analysis of dangerous factors, the degree of significant influence and probability of potential dangers were determined. Significant potential hazards have been identified at such technological stages as insemination and incubation of caviar, larval survival, caviar, larvae, young, commodity fish and pedigree.

Biological filter is defined as a key link in the RAS the functioning of which effects on the quality and safety of commercial fish. It carries out aerobic and anaerobic processes to remove contaminations in the form of ammonium producing by fish, and carbon dioxide, which is formed from undigested food and feces. There are such dangerous factors on the stage of biological purification of water: biological - possible exceeding the total microbial number (more than $100 \mathrm{CFU} / \mathrm{cm}^{3}$ ), the number of nitrifying (more than $\left.10^{6} \mathrm{CFU} / \mathrm{cm}^{3}\right)$ and E. coli group bacteria, the presence of bacteria Pseudomonas aeruginosa; chemical - exceeding the content of nitrates (more than $50 \mathrm{mg} / \mathrm{dm}^{3}$ ), nitrites (more than $0.5 \mathrm{mg} / \mathrm{dm}^{3}$ ), $\mathrm{pH}$ - above 8 .

In addition to purely technological, there are additional dangerous factors - related to the functioning of the biofilter, fish feeding and the use of veterinary preparations and disinfectants. The potential hazards identified in the work are important to be taken into account in the process of implementation of Rainbow Trout HACCP plan.
\end{abstract}

Key words: dangerous factor, HACCP, control critical points, aquaculture, rainbow trout, Recirculating aquaculture systems.

\section{Ветуп}

Аквакультура та рибництво сьогодні належать до таких видів економічної діяльності, які можуть значно поліпшити продовольчий баланс та позитивно вплинути на підвищення рівня продовольчої безпеки в Україні. Зважаючи на активність держави в будівництві нового якісного правового поля у взаємовідносинах між суб' єктами права, створенні нової ефективної економічної політики та євроінтеграційних процесів, сучасне рибне господарство також потребує якісних структурних змін. Вони мають відбутись передусім у системі надання послуг, якості продукції, ефективного, ресурсоощадного та екологічного виробництва.

Відповідно до Закону України «Про основні принципи та вимоги до безпечності та якості харчових продуктів», «особи, які займаються виробництвом або введенням в обіг харчових продуктів, повинні застосовувати санітарні заходи та належну практику виробництва, системи НАССР та/або інші системи забезпечення безпечності та якості під час виробництва та обігу харчових продуктів..» (Zakon Ukrainy, 2014).

Актуальність. Виробники харчової продукції, сировиною для яких $є$ необроблені м'ясо та м'ясні продукти, риба та рибні продукти, молоко, яйця, мають впровадити процедури, які базуються на принципах НАССР, до 20 вересня 2017 року, всі інші виробники - до 20 вересня 2018, а малі потужності матимуть для цього ще один рік.
Крім того, Президентом України було підписано Закон України «Про державний контроль, що здійснюється 3 метою перевірки відповідності законодавству про безпечність та якість харчових продуктів і кормів, здоров'я та благополуччя тварин», що вступає в силу 34 квітня 2018 року (Slyva, 2017).

На жаль, сьогодні у вітчизняній аквакультурі лише на кількох індустріальних підприємствах запроваджено систему НАССР, не здійснюються відповідні заходи 3 імплементації в українське законодавство відповідних актів СС в частині ветеринарного та санітарного забезпечення, умов утримання риб, умов перевезення живої риби тощо. Для виходу української продукції аквакультури на зовнішні ринки ці заходи необхідно здійснювати негайно.

Обов'язковим i першочерговим для виконання етапом впровадження системи НАССР є ідентифікація небезпечних чинників, які можуть виникати на всіх стадіях виробництва харчової продукції. Ідентифікація і оцінювання всіх обгрунтовано очікуваних ризиків $\epsilon$ ефективними та економічно доцільними заходами у гарантуванні безпеки харчової продукції аквакультури .

Метою $i$ завданнями досліджень було визначення небезпечних чинників, які можуть виникати під час вирощування райдужної форелі на всіх етапах виробничого циклу в умовах замкнутого водопостачання. 


\section{Матеріал і методи досліджень}

Ідентифікацію небезпечних чинників здійснювали для умовного індустріального господарства 3 вирощування райдужної форелі в умовах замкнутого водопостачання. Принципову схему повносистемного форелевого господарства, яка включає рибоводний та інженерно-технічний блоки, подано на рисунку 1.
Зазвичай повний цикл вирощування форелі у господарстві включає технологічні етапи вирощування та реалізації харчової і рибоводної продукції. Важливими ланками технологічного процесу $є$ використання кормів і застосування лікувально-профілактичних та дезінфекційних препаратів (рис. 2).

Рибоводний блок

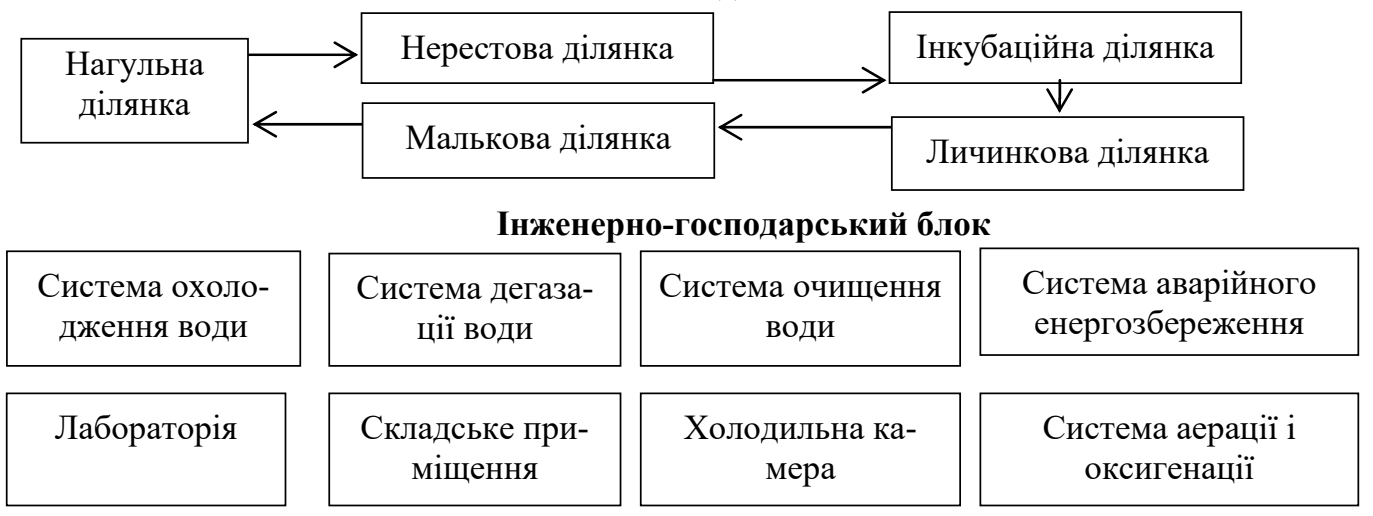

Рис. 1. Принципова схема повносистемного форелевого господарства

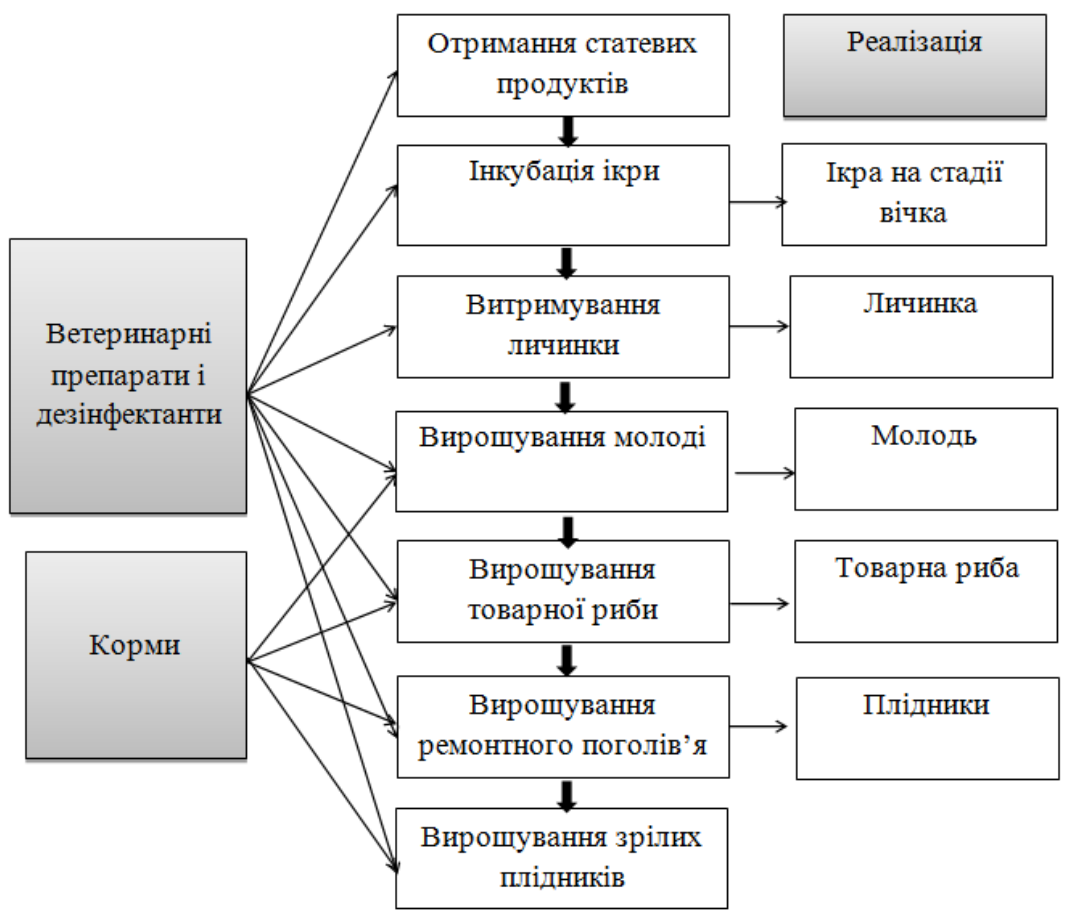

Рис. 2. Схема технологічного процесу вирощування форелі

Крім того, господарство може вирішувати широке коло питань, пов'язаних з формуванням та експлуатацією племінних стад риб для цілей штучного відтворення і товарного рибництва, включаючи отримання ікри, а також селекційно-племінної роботи.
Під час аналізу небезпечних чинників визначали ступінь суттєвого впливу і вірогідності потенційних небезпек за шкалами, наведеними у табл. 1, 2 (Vasylenko et al., 2011). 
Ступінь суттєвості та шкала оцінки небезпечних чинників на здоров'я людини

\begin{tabular}{|l|c|c|}
\hline \multicolumn{1}{|c|}{ Наслідки для здоров’я людини } & Ступінь суттєвості впливу & Шкала оцінки, бал \\
\hline Летальний результат & Критичний & 1 \\
\hline $\begin{array}{l}\text { Важке захворювання, яке потребує госпіталізації або загрожує } \\
\text { інвалідністю }\end{array}$ & Високий & 2 \\
\hline Захворювання, яке призводить до тимчасової непрацездатності & Середній & 3 \\
\hline Несуттєве погіршення здоров'я & Низький & 4 \\
\hline
\end{tabular}

Критерії оцінки вірогідності виникнення небезпечних чинників

\begin{tabular}{|l|c|c|}
\hline \multicolumn{1}{|c|}{ Вірогідність виникнення } & Ступінь вірогідності & Шкала оцінки, бал \\
\hline $\begin{array}{l}\text { Є випадки виникнення або перевищення на підприємстві, або } \\
\text { існує вірогідність цього від одного разу за зміну чи частіше }\end{array}$ & Високий & 1 \\
\hline $\begin{array}{l}\text { Є випадки виникнення або перевищення на подібних підпри- } \\
\text { єствах, або існує вірогідність цього на підприємстві від декі- } \\
\text { лькох разів на місяць до одного разу за зміну }\end{array}$ & Середній & 2 \\
\hline $\begin{array}{l}\text { Продукт є мікробіологічно чутливим або існує вірогідність } \\
\text { порушення процедури, рецептур, заходів управління привне- } \\
\text { сення чи забруднення від декількох разів на рік до одного разу } \\
\text { на місяць }\end{array}$ & Незначний & 3 \\
\hline $\begin{array}{l}\text { Практичний досвід виробництва й контролю продукції та } \\
\text { наукові дані свідчать про малу вірогідність виникнення або } \\
\text { посилення небезпечного чинника від одного разу на рік і } \\
\text { рідше }\end{array}$ & Практично дорівнює нулю & 4 \\
\hline
\end{tabular}

\section{Результати та їх обговорення}

Ідентифікацію небезпечних чинників для умовного індустріального форелевого господарства проводили, беручи до уваги, що система гарантування безпеки продукції аквакультури має орієнтуватись на харчовий продукт, безпечний для людини в момент споживання, і на захист здоров'я самих об'єктів аквакультури.

На технологічному етапі отримання статевих продуктів здійснюється переведення плідників на нерестову температуру, стимуляція дозрівання. Проводиться спостереження за початком овуляції і спермізації. Ікру і сперму у плідників форелі отримують шляхом відціджування. До параметрів, які контролюються на даному етапі, належать ступінь зрілості ооцитів та якість сперми. Відповідно до критеріїв, зазначених у таблицях 1 і 2, на цьому етапі ступінь настання небезпечного випадку низький.

Для осіменіння ікру і сперму змішують у ємностях 3 додаванням води. Для підвищення заплідненості ікри замість води рекомендується доливати розчин Хамора. Інкубацію зазвичай проводять у спеціальних апаратах. До небажаних процесів, які можуть мати місце у цей період і негативно впливати на виробничий процес, якість і безпечність кінцевої продукції, можна віднести низький відсоток запліднення, аномалії у розвитку ембріонів, зміну гідрохімічних параметрів. Може розвиватись сапролегніоз ікри, що і $є$ небезпечним чинником на даному етапі. У разі впровадження плану НАССР у форелевому господарстві тут може бути визначено контрольну критичну точку (ККТ). На даному етапі контролюють відсоток запліднення і частку ембріонів, які типово (нормально) розвиваються, синхронність розвитку зародків. Надзвичайно важливими є гідрохімічні показники. Вміст розчиненого у воді кисню не має перевищувати
7,5 мг/л, рН середовища - 7-8, концентрація амонійного азоту - не більш як 1 мг/л. Гранична концентрація амоніаку - не більш як 0,05 мг/л. Водообмін - не менш як 1,5 об'ємів/год. Температура $-14-18{ }^{\circ} \mathrm{C}$, іiі добові коливання не мають бути більшими ніж $2{ }^{\circ} \mathrm{C}$.

Процес витримування личинки забезпечує сприятливі умови для активного живлення і соматичного росту. Таких умов досягають за рахунок підтримання оптимальної температури, якісного очищення води i повноцінної годівлі. Наявність небезпечних чинників на даному технологічному етапі пов'язана 3 порушенням температурного режиму та роботи систем очищення води, використанням кормів, які не відповідають харчовим потребам молоді та їі розмірам. Важливо контролювати гідрохімічні показники (вміст кисню - 7-9 мг/л, рН - 7-8, концентрація амонійного азоту не більш як 1 мг/л, гранична концентрація амоніаку не більш як 0,05 мг/л). Бажано, щоб водообмін був не менш як 1 об'єм/год, температура води $-8-14{ }^{\circ} \mathrm{C}$. Контролюють також масу личинок і молоді. 3 огляду на ідентифіковані небезпечні чинники на даному етапі бажано визначити ККТ.

Технологічні етапи вирощування молоді, товарної риби, ремонтного молодняку та плідників подібні метою забезпечення сприятливих умов для живлення i росту риби. Як і в попередньому випадку, небезпечні чинники пов'язані 3 гідрохімічними показниками, температурним режимом та годівлею.

Якщо на стадії вирощування різних груп риб ідентифіковані небезпечні чинники є несуттєвими, то на стадії реалізації вже виникає необхідність визначати ККТ. Всі небезпечні чинники на стадії реалізації пов'язані $з$ транспортуванням. Так, на етапі реалізації ікри на стадії вічка неналежні умови транспортування можуть призвести до припинення розвитку личинки анатомічних порушень і загибелі. У всіх випадках $є$ загроза порушення герметичності упаковки, темпера- 
турного режиму. Крім того, на стадії реалізації молоді, товарної риби і плідників небезпечним чинником $\epsilon$ нагодована риба. Відповідно до гігієнічних вимог, за три доби до транспортування годівлю форелі припиняють.

Однією 3 ключових ланок рециркуляційної системи в установках замкнутого водопостачання (УЗВ) є біологічний фільтр. Він здійснює аеробні та анаеробні процеси 3 метою видалення забруднень у формі амонію, який продукують риби, та вуглекислого газу, який утворюється із неспожитого корму і фекалій (Schreier et al., 2010). Від функціонування біофільтра значною мірою залежить якість та безпечність товарної риби, яка вирощується в УЗВ. До небезпечних чинників, які ідентифікуються на стадії біологічного очищення води, можна віднести біологічні - перевищення загального мікробного числа $\left(100 \mathrm{KУО} / \mathrm{cm}^{3}\right)$, кількості нітрифікуючих бактерій (більш як $10^{6}$ $\left.\mathrm{KУO} / \mathrm{cm}^{3}\right)$, бактерій групи кишкової палички, наявність бактерій Pseudomonas aeruginjsa та хімічні -

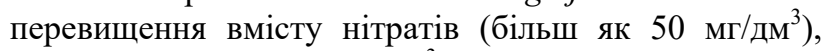
нітритів (більш як 0,5 мг/дм³ $), \mathrm{pH}-$ вище 8 .

Додатково до суто технологічних небезпечних чинників можна ідентифікувати ризики, пов'язані 3 годівлею риби та застосуванням лікувальнопрофілактичних і дезінфекційних препаратів. Корми, які використовуються на підприємствах аквакультури, мають відповідати «Нормам і правилам годівлі тварин» (Codex Alementarius, 2004). Можливими небезпечними чинниками, пов'язаними 3 кормами, $€$ хімічне (пестициди, антиоксиданти та ін.) та мікробіологічне (патогенні бактерії) забруднення і мікотоксини. Залишкові кількості ветеринарних препаратів, використовуваних для лікування і профілактики захворювань об'єктів аквакультури, є хімічними небезпечними чинниками. Відсутність в Україні державної системи моніторингу залишкових кількостей небезпечних для здоров'я людини речовин $є$ перепоною для експорту продукції аквакультури у європейські країни.

У ході ідентифікації та оцінювання потенційної небезпеки в умовах форелевого господарства важливо враховувати не тільки виробничі, а й супровідні виробництву елементи, зокрема пов'язані з постачанням кормів, досвідом і кваліфікацією персоналу, зовнішнім середовищем тощо. Тобто аналізу піддаються потенційні загрози як внутрішнього, так і зовнішнього походження.

\section{Висновки}

Таким чином, під час вирощування райдужної форелі у системах із замкнутим водопостачанням суттєві небезпечні чинники ідентифікуються на таких технологічних етапах, як осіменіння та інкубація ікри, витримування личинки, реалізація ікри, личинки, молоді, товарної риби і плідників. Крім суто технологічних, мають місце додаткові небезпечні чинники пов'язані з функціонуванням біофільтра, годівлею i застосуванням лікувально-профілактичних та дезінфекційних засобів. Ідентифіковані в роботі потенційні небезпеки важливо враховувати під час складання плану НАССР у господарствах з вирощування райдужної форелі в умовах замкнутого водопостачання.

\section{Бібліографічні посилання}

Zakon Ukrainy (2014). «Pro osnovni pryntsypy ta vymohy do bezpechnosti ta yakosti kharchovykh produktiv. № 1602-VII vid 22 lypnia 2014 roku (in Ukrainian).

Vasylenko, H., Dorofieieva, O., Holub, B., Myroniuk, H. (2011). Posibnyk dlia malykh ta serednikh pidpryiemstv miasopererobnoi haluzi z pidhotovky ta vprovadzhennia systemy upravlinnia bezpechnistiu kharchovykh produktiv na osnovi kontseptsii NASSR. K.: Mizhnarodnyi instytut bezpechnosti ta yakosti kharchovykh produktiv, 236 (in Ukrainian).

Slyva, Yu. (2017). Shcho slid vrakhovuvaty, vprovadzhuiuchy NASSR na pidpryiemstvi. Elektronnyi resurs: http://agravery.com/uk/posts/ author/show?slug=so-slid-vrahovuvati-vprovadzuucinassr-na-pidpriemstvi (in Ukrainian).

Codex Alementarius (2004). CAC/RCP 54-2004 Code of Practice on Good Animal Feeding http://www.fao.org/docrep/012/i1379e/i1379e06.pdf

Schreier, H.J., Mirzoyan, N., Saito, K. (2010). Microbial diversity of biological filters in recirculating aquaculture systems. Current Opinion in Biotechnology. 21, 318-325.

Received 7.09.2017 Received in revised form 30.09.2017 Accepted 3.10.2017 